\title{
GURU: IDEOLOGI DAN PROFESI
}

\author{
Duski Samad \\ Guru Besar pada Fakultas Tarbiyah IAIN Imam Bonjol Padang \\ e-mail: duski_samad@yahoo.com
}

\begin{abstract}
Abstract: Teaching profession is not a common job, it carries certain sets of ideology. A teacher who is committed to certain ideology will likely to be more successful and highly appreciated in pursuing her career. It has already been proved through the history that best teachers are born among individuals who possessed pedagogical ideology. Great cares have been continuously given by the Government to improve teachers' lives and positions through Law number 14 year 2005 dealing with teacher and lecturer. The improvement of teacher's status as professional staff has brought about wide impacts. Its positive impact is that teacher position becomes more prestigious and it affects to the betterment of their welfares. However, there is a critique to the procedures of certification that it doesn't provide significant impact to the quality improvement of education.
\end{abstract}

Key words: teacher, professional teacher, profession, and ideology

\begin{abstract}
Abstrak: Menjadi guru adalah pekerjaan mulia dan strategis. Pilihan profesi sebagai guru tidak sekedar pekerjaan biasa, akan tetapi ia memiliki muatan ideology. Seorang guru yang mengajar dan menetapkan pilihannya menjadi guru dengan didasarkan pada ideology akan lebih sukses dan bernilai tinggi. Sejarah membuktikan guru-guru teladan dan terbaik lazimnya hadir pada individu yang memiliki ideology pendidik. Pendidikan guru adalah komponen penting untuk tercapainya tujuan pendidikan. Perhatian pemerintah terhadap kehidupan dan kedudukan guru terus meningkat, khususnya setelah ditetapkannya undang-undang Nomor 14 tahun 2005 tentang guru dan dosen. Peningkatan status guru sebagai profesi dan akhirnya berimplikasi pada sertifikasi, telah membawa dampak yang luas. Dampak positifnya menjadikan guru jabatan bergensi dan meningkatnya kesejahteraan guru. Di pihak lain, ada kritikan bahwa sertifikasi belum memberikan dampak berarti bagi peningkatan mutu pendidikan.
\end{abstract}

Kata Kunci: guru, guru profesional, profesi, dan ideologi.

\section{PENDAHULUAN}

Guru senior yang mengajar sebelum tahun 1980-an sering mengatakan guru sekarang sudah senang, tunjangan sertifikasi lumayan, mengajar didukung sarana lengkap dan harga diri sudah terangkat pula, sedangkan kami dulu gaji kecil, profesi kurang dihargai dan gaji paspasan tiap bulan. Namun, dari segi kualitas mengajar dan kesetiaan pada profesi guru dulu jauh lebih baik dan menghasilkan tamatan yang lebih berkarakter, sementara guru pasca sertifikasi patut dipertanyakan kualitas pengajarannya dan anak didik yang dihasilkannya.

Pertanyaan senada hampir selalu menjadi perbincangan setiap kali akhir tahun karena berkaitan dengan angka kelulusan siswa, begitu juga di awal tahun ketika anak-anak didik akan melanjutkan ke sekolah lebih tinggi. Perdebatan tentang sertifikasi guru dan keterkaitannya dengan kualitas pendidikan nasional, tidak bisa dijawab mudah dan sederhana begitu saja, karena soal pendidikan memiliki dimensi luas.

Guru adalah unsur pokok dalam pendidikan dan pengajaran. Membicarakan pendidikan jenis apa saja, masalah utama yang perlu mendapat perhatian adalah soal bagaimana guru. Guru, apalagi guru agama, adalah misi kehidupan dan juga misi ideologi. Ketika, guru menjadi key point dalam pendidikan maka tentu kompetensi dan keprofesionalan guru adalah hal yang harus diperhatikan pengelola pendidikan, penentu kebijakan pendidikan dan pihak-pihak terkait dengan dunia pendidikan.

Diskursus tentang guru dalam makna ideology dengan guru sebagai profesi patut dikaji dan ditempatkan secara proporsional. Keterpaduan dua konsep kunci ini akan 
memberikan jalan keluar bagi tercapainya tujuan pendidikan nasional.

\section{GURU PROFESIONAL}

Perhatian pemerintah untuk memastikan kualitas pendidik sudah ditegaskan dalam pasal 35 ayat (1) Undang-Undang Republik Indonesia nomor 20 tahun 2003 tentang Sistem Pendidikan Nasional bahwa standar nasional pendidikan yang terdiri atas standar isi, standar proses, standar kompetensi lulusan, standar tenaga kependidikan, standar sarana dan prasarana, standar pengelolaan, standar pembiayaan, dan standar penilaian pendidikan harus ditingkatkan secara berencana dan berkala.

Undang-undang Nomor 20 Tahun 2003 tentang Sistim Pendidikan Nasional pada pasal 42 ayat (1) menjelaskan "pendidik harus memiliki kualifikasi menimum dan sertifikasi sesuai dengan jenjang kewenangan mengajar, sehat jasmani dan rohani, serta memiliki kemampuan untuk mewujudkan tujuan pendidikan nasional" pasal tersebut di atas memuat dua hal pokok yang harus dimiliki seorang guru yaitu kualifikasi akademik jenjang pendidikan strata 1 dan atau $\mathrm{D} 1 \mathrm{~V}$ dan pengakuan profesional melalui jalur sertifikasi guru.

Undang-undang Guru merupakan suatu ketetapan politik bahwa pendidik adalah pekerja profesional,yang berhak mendapatkan hak-hak sekaligus kewajiban profesional. Dengan itu diharapkan,pendidik dapat mengabdikan secara total pada profesinya dan dapat hidup layak dari profesi tersebut. Dalam UUGD no 14 tahun 2005 ditentukan bahwa seorang pendidik wajib memiliki kualifikasi akademik dan kompetensi pendidik sebagai agen pembelajaran. Kompetensi profesi pendidik meliputi kompetensi pedagogik, kompetensi kepribadian, kompetensi profesional, dan kompetensi sosial.

Pertama, kompetensi pedagogik. Adalah kemampuan mengelola pembelajaran peserta didik yang meliputi pemahaman terhadap peserta didik, perancangan dan pelaksanaan pembelajaran, evaluasi hasil belajar, dan pengembangan peserta didik untuk mengaktualisasikan berbagai potensi yang dimilikinya. Kedua, kompetensi kepribadian. Adalah kepribadian pendidik yang mantap, stabil, dewasa, arif, dan berwibawa, menjadi teladan bagi peserta didik, dan berakhlak mulia. Ketiga, kompetensi sosial. Adalah kemampuan pendidik berkomunikasi dan berinteraksi secara efektif dengan peserta didik, sesama pendidik, tenaga kependidikan, orangtua/wali peserta didik, dan masyarakat. Keempat, kompetensi profesional. Adalah kemampuan pendidik dalam penguasaan materi pembela-jaran secara luas dan mendalam yang memungkinkannya membimbing peserta didik mem-peroleh kompetensi yang ditetapkan.

Keberadaan guru dan peningkatan kualitas atau profesional guru juga sudah ditetapkan Undang-Undang Republik Indonesia nomor 14 tahun 2005 tentang Guru dan Dosen. Undang-undang itu dinyatakan bahwa guru adalah pendidik profesional dengan tugas utama mendidik, mengajar, membimbing, mengarahkan, melatih, menilai, dan mengevaluasi peserta didik pada pendidikan anak usia dini jalur pendidikan formal, pendidikan dasar, dan pendidikan menengah. Pasal 7 ayat (1) Undang-undang Republik Indonesia nomor 14 tahun 2005 menyatakan bahwa profesi guru dan profesi dosen merupakan bidang pekerjaan khusus yang dilaksanakan berdasarkan prinsip sebagai berikut, (a) memiliki bakat, minat, panggilan jiwa, dan idealisme; (b) memiliki komitmen untuk meningkatkan mutu pendidikan, keimanan, ketakwaan, dan akhlak mulia; (c) memiliki kualifikasi akademik dan latar belakang pendidikan sesuai dengan bidang tugas; (d) memiliki kompetensi yang diperlukan sesuai dengan bidang tugas; (e) memiliki tanggung jawab atas pelaksanaan tugas keprofesionalan; (f) memperoleh penghasilan yang ditentukan sesuai dengan prestasi kerja; (g) memiliki kesempatan untuk mengem-bangkan keprofesionalan secara berkelanjutan dengan belajar sepanjang hayat; (h) memiliki jaminan perlindungan hukum dalam melak-sanakan tugas keprofesionalan; dan (i) memiliki organisasi profesi yang mempunyai kewenangan mengatur hal-hal yang berkaitan dengan tugas keprofesionalan guru. 
Undang-undang yang ada menunjukkan perlunya keterukuran profesio-nalitas seorang guru. Secara yuridis sudah dipastikan bahwa guru adalah profesi. Profesi guru sebagai jabatan profesional tentu harus memenuhi kreteria-kreteria khusus. Profesional adalah pekerjaan atau kegiatan yang dilakukan oleh seseorang dan menjadi sumber penghasilan kehidupan yang memerlukan keahlian, kemahiran, atau kecakapan yang memenuhi standar mutu atau norma tertentu serta memerlukan pendidikan profesi. Guru sebagai tenaga profesional mengandung arti bahwa pekerjaan guru hanya dapat dilakukan oleh seseorang yang mempunyai kualifikasi akademik, kompetensi, dan sertifikat pendidik sesuai dengan persyaratan untuk setiap jenis dan jenjang pendidikan tertentu.

Guru dalam melaksanakan tugas keprofesionalan, guru berkewajiban, (1) merencanakan pembelajaran, melaksanakan proses pembelajaran yang bermutu, serta menilai dan mengevaluasi hasil pembelajaran; (2) meningkatkan dan mengembangkan kualifikasi akademik dan kompetensi secara berkelanjutan sejalan dengan perkembangan ilmu pengetahuan, teknologi, dan seni; (3) bertindak objektif dan tidak diskriminatif atas dasar pertimbangan jenis kelamin, agama, suku, ras, dan kondisi fisik tertentu, atau latar belakang keluarga, dan status sosial ekonomi peserta didik dalam pembelajaran; (4) menjunjung tinggi peraturan perundang-undangan, hukum, dan kode etik guru, serta nilai-nilai agama dan etika; dan (4) Memelihara dan memupuk persatuan dan kesatuan bangsa.

Kedudukan guru sebagai tenaga profesional sebagaimana dimaksud dalam Pasal 2 ayat (1) berfungsi untuk meningkatkan martabat dan peran guru sebagai agen pembelajaran berfungsi untuk meningkatkan mutu pendidikan nasional. Yang dimaksud dengan guru sebagai agen pembelajaran (learning agent) adalah peran guru antara lain sebagai fasilitator, motivator, pemacu, perekayasa pembelajaran, dan pemberi inspirasi belajar bagi peserta didik.

\section{GURU SEBAGAI IDEOLOGI.}

Menjadi guru dengan tugas utama menyebarluaskan ilmu pengetahuan adalah pekerjaan mulia dan memiliki derajat tinggi. Allah Swt meninggikan derajat orang-orang yang berilmu (berprofesi sebagai guru) beberapa derajat di atas profesi lainnya (QS. AlMujadalah, 85:11). Lebih dari itu ditegaskan oeh Rasul Muhammad Saw, belajar dan mengajar adalah kewajiban bagi laki-laki dan perempuan (al-hadis). Dalam hadis lain dinyatakan pula, bahwa siapa saja yang menekuni profesi sebagai guru maka Allah Swt membetangkan jalan lurus dan mudah ke sorga.

Norma ayat dan hadis di atas menyatakan bahwa menjadi guru harus disertai dengan ideologi atau keyakinan yang kuat. Keyakinan yang kokoh dari seorang guru dengan sendirinya akan menjadikan ia profesional. Guru profesional pada dasarnya adalah guru yang bekerja didasarkan pada ideologi. Kinerja guru profesional tercermin dalam penampilan pelaksanaan tugas-tugas yang ditandai dengan keahlian baik dalam materi maupun metode.

Dengan keahliannya itu, seorang guru mampu menunjukkan otonominya, baik pribadi maupun sebagai pemangku profesinya. Sosok profesional guru dapat ditunjukkan melalui tanggung jawabnya dalam melaksanakan seluruh pengabdiannya profesio-nal, dan kemampuannya memikul dan melak-sanakan tanggung sebagai sebagai guru kepada peserta didik, orang tua, masyarakat, bangsa negara, dan agamanya. Lebih tegas dapat dikatakan bahwa guru profesional mempunyai tanggung jawab sosial, intelektual, moral dan spiritual.

Tanggung jawab pribadi yang mandiri yang mampu memahami dirinya, mengelola dirinya, mengendalikan dirinya menghargai serta mengembangkan dirinya. Tanggung jawab sosial diwujudkan melalui kompetensi guru 
dalam memahami dirinya sebagai bagian yang tak terpisahkan dari lingkungan sosial serta memiliki kemampuan interaksi yang efektif. Tanggung jawab intelektual diwujudkan melalui penguasaan berbagai perangkat pengetahuan dan keterampilan yang diperlukan untuk menunjang tugas-tugasnya. Tanggung jawab spiritual dan moral diwujudkan melalui penampilan guru sebagai makhluk yang beragama yang perilakunya senantiasa tidak menyimpang dari norma-norma agama dan moral.

Kaidah-kaidah guru profesional sebagaimana di atas, bila ditelisik dalam pengertian ideologi seorang guru, maka dapat disimpulkan bahwa sesungguhnya guru profesional itu adalah guru yang sudah berkerja dengan landasan ideologi. Kritikan tentang belum maksimal pembelajaran yang dilakukan guru dikarenakan lemahnya ideologi seorang guru, adalah sesuatu yang tidak sepenuhnya benar. Kemampuan, kesungguhan dan kompotensi guru dalam melaksanakan tugasnya memang didorong bukan sekedar sertifikasi, akan tetapi muatan ideologi berperan sekali.

Guru yang melakukan tugas didasarkan pada keyakinan bahwa mengajar itu adalah ibadah dan jadi guru pekerjaan mulia, maka hasil kinerja guru tersebut lebih baik. Guru yang asal pendidikannya dari sekolah keguruan, menjadi guru karena panggilan bakat, suara nuraninya memang menjadi pendidik dalam realitasnya akan lebih sukses ketika diperkuat lagi dengan tunjangan sertifikasi.

\section{SIMPULAN}

Sebagai bahagian akhir dapat dikatakan bahwa aturan, norma dan panduan untuk meningkatkan profesionalitas guru yang sudah dibakukan pemerintah dalam berbagai skema, dan kemudian sudah dilaksanakan pula sertifikasi guru, diberikan lagi tunjangan sertifikasi sebesar satu kali gaji pokok, realitasnya dunia pendidikan dan kualitas anak-anak didik masih belum cukup kuat peningkatannya. Munculnya kasus-kasus tawuran pelajar, ujian nasional yang tidak fair, dan sederetan masalah siswa adalah potret pendidikan yang masih bermasalah. Dunia pendidikan ditenggarai belum mampu mencapai tujuan pendidikan yang diharapkan. Guru sebagai pendidik masih belum cukup mampu mempertanggung jawab tugastugas profesionalitasnya. Guru berserfikasi sekalipun masih saja belum berarti banyak bagi kemajuan pendidikan nasional. Demikian keluhan, dan kritikan banyak pihak tentang profesionalitas guru pasca sertifikasi.

Guru yang bekerja dengan ideologi yang sehat dan kemudian ditambah dengan sertifikasi serta pendidikan keprofesionalan diyakini dapat mempercepat kualitas pendidikan. Sertifikasi berikut tunjangan yang menyertai tidak serta merta dapat meningkatkan kinerja guru yang pada akhirnya memajukan kualitas pendidikan. Tugas semua pihak yang terkait dengan dunia pendidikan adalah memperkokoh, membiasakan, menumbuhkembangkan motivasi ideologi para guru, guna mencapai tujuan pendidikan. Back to basic bahwa mengajar adalah ibadah dan menjadi guru itu profesi mulia adalah kunci pokok untuk tercapai kinerja maksimal.

\section{DAFTAR RUJUKAN}

Al Rasyidin. 2009. Percikan Pemikiran Pendidikan dari Filsafat Hingga Praktek Pendidikan, Bandung: Cita Pustaka Media Perintis.

Al Rasyidin. 2008. Falsafah Pendidikan Islam Membangun Kerangka Ontologi, Epistimologi dan Aksiologi Praktik Pendidikan, Badung: Cita Pustaka Media Perintis.

Muhaimin. 2011. Pemikiran dan Aktulisasi Pengembangan Pendidikan Islam, Jakarta: PT.Rajawali Press. 
Muhammad Kosim. 2012. Pemikiran Pendidikan Islam Ibnu Khaldun, Kritis, Humanis dan Religius, Jakarta: Renika Cipta

Undang No.14 Tahun 2005 tentang Guru dan Dosen.

Undang-Undang No.20 tahun 2003 Tentang Sistim Pendidikan Nasional.

Zainuddin, ddk. 2009. Pendidikan Islam Dari Paradigma Klasik Hingga Kotemporer, UIN Malang Press. 